\title{
Boneka Gender: Implementasi Metode Proyek Pendidikan Gender Pada Calon Guru PAUD
}

\author{
Wahju Dyah laksmi Wardhani ${ }^{1)}$, Nita Puspitasari ${ }^{2)}$, Eka Dwi Lestari ${ }^{3)}$, \\ Agnes Sulistianingsih ${ }^{4)}$, Lucky Mariana ${ }^{5)}$, Khotibatul Hasanah ${ }^{6}$ \\ Universitas Muhammadiyah Jember \\ Email: dyahlaksmi_paud@unmuhjember.ac.id \\ nitapuspitasari747@gmail.com
}

\begin{abstract}
Abstrak:
Tujuan dari penelitian ini adalah untuk mendeskripsikan kemampuan calon guru Pendidikan Anak Usia Dini (PAUD) dalam merancang dan melaksanakan pembelajaran berwawasan gender pada anak usia dini. Penelitian ini berjenis penelitian kualitatif dengan subyek lima orang mahasiswa peserta mata kuliah Wawasan Gender di program studi Pendidikan Guru Pendidikan Anak Usia Dini (PG PAUD) Universitas Muhammadiyah Jember (UMJ). Sebagian mahasiswa peserta mata kuliah ini telah menjadi guru di lembaga PAUD, namun mereka menyadari bahwa di dalam pembelajaran tentang gender untuk anak belum terlalu baik. Dalam pengembangan proses pembelajaran mata kuliah Wawasan Gender ini selanjutnya, mahasiswa di bagi dalam lima kelompok yang melaksanakan proyek mulai dari rancangan pengembangan skenario pembelajaran gender untuk anak kelompok 5 sampai 6 tahun, penyiapan media belajar serta simulasi dalam kelompok terbatas di lapangan. Media pembelajaran dan rencana implementasi lapangan di kembangkan pada paruh semester usai ujian tengah semester dengan menggunakan skenario pembelajaran yang sudah di rancang saat sebelum ujian tengah semester. Hasil yang di peroleh mahasiswa setelah menerapkan media boneka gender dan skenario pembelajaran di lapangan secara terbatas menunjukkan bahwa siswa lebih mudah memahami konsep-konsep gender serta peran gender yang lebih abstrak melalui media boneka gender.
\end{abstract}

Kata Kunci: metode proyek, wawasan gender

\section{PENDAhUluan}

Keberadaan seorang anak selalu dihubungkan dengan keluarga, komunitas, budaya dan lingkungan tempat tinggal. Perkembangan dan pembelajaran yang dialami anak dipengaruhi oleh hubungan antara keluarga, komunitas, budaya dan 
leingkungan tempat tinggal bahkan sejak anak tersebut belum dilahirkan. Keluarga merupakan lembaga belajar pertama yang dikenal oleh anak dan memiliki pengaruh yang sangat kuat pada saat anak memasuki lingkungan sosial di luar keluarga.

Pada tahap usia tertentu, anak memasuki lingkungan sosial yang lebih luas dalam kehidupan sehari-harinya, anak mengembangkan minat dan mengkonstruksi identitas dirinya dan pemahaman akan nilai-nilai yang menyelaraskan hubungan anak dengan dunia luar. Hal ini yang terjadi saat anak memasuki dunia persekolahan pertamanya. Saat masuk ke Pendidikan Anak Usia Dini (PAUD), anak memasuki masa transisi lingkungan sosial dengan anak sebaya yang lebih luas. Anak memperoleh pengalaman belajar baru yang melengkapi pengalaman belajar yang diperoleh dari keluarganya. Di sekolah anak belajar untuk mengetahui, melakukan, beradaptasi dan berinteraksi sosial dengan masyarakat.

Pada masa ini anak mengalami perkembangan pengetahuan dan pemahaman tentang identitas dirinya yang lebih komplek dari sekedar identitas dan kedudukannya di keluarga. Saat di keluarga anak dikenal sebagai mas, mbak, kakak atau adik, atau anak mengenal dirinya sebagai anak laki-laki atau anak perempuan atau bahkan anak belum memiliki kesadaran akan jenis kelaminnya karena tidak pernah dikenalkan secara konstruktif oleh orang tua atau anggota keluarga yang lain. Henniger (2013;365) mengatakan bahwa keluarga adalah peletak dasar interaksi yang tepat atau tidak tepat, terlebih pada pengembangan kemampuan sosial dan emosional anak. Sedangkan Bandura (Santrock, 2002;283) menyatakan bahwa perkembangan gender anak terjadi melalui observasi dan peniruan perilaku gender, melalui mekanisme hadiah dan hukuman

Pernyataan-pernyataan seperti mau pakai jepit rambut kaya mbak atau mau pakai sarung kayak ayah atau mau pakai lipstick biar cantik merupakan suatu hal yang dianggap pernyataan lucu belaka. Namun bila kita memahami pemaknaan akan kesadaran identitas jenis kelamin atau personalitas anak maka akan muncul keprihatinan karena menyadari adanya bias pengetahuan anak akan identitasnya. Pernyataan pakai jepit rambut atau pakai lipstick agar tampil cantik tentu tidak lagi terasa lucu bila yang menyatakan adalah anak laki-laki. Sebaliknya, pernyataan tentang pakai sarung seperti ayah akan jadi kurang pantas bila dinyatakan oleh anak perempuan. Atribut-atribut jepit, lipstick, sarung (dalam konteks baju untuk sholat) melekat pada jenis kelamin tertentu, sehingga bila yang menyatakan hal tersebut dikatakan oleh yang bukan pengguna pada umumnya akan terasa kejanggalannya. 
Pemahaman akan jenis kelamin ini memperkaya anak akan kemungkinan belajar tentang konsekuensi identitas diri terkait dengan peran yang dapat dilakukannya. Peran seseorang seringkali dikaitkan dengan istilah gender. Orang tua memiliki andil yang besar dengan model pengasuhan dalam membentuk identitas gender anak. Wardhani (2017) mengkategorisasikan 3 pola pembentukan gender oleh orang tua Kategori pertama, pola bias diartikan bahwa pola konstruksi anak terhadap atribut tertentu tidak dikontrol secara ketat oleh orang tua namun pada atribut lain orang tua berperan untuk memilih dan mengarahkan tindakan anak. Kategori kedua, pola konstruktif yang ditandai oleh peran dominan orang tua dalam memilih dan mengarahkan anak pada kegiatan maupun barang pribadi seperti alat bermain, baju bahkan teman bermain anak yang disesuaikan dengan jenis kelamin anak. Kategori ketiga, pola bebas nampak pada keputusan orang tua untuk memberi kebebasan sepenuhnya pada atribut-atribut pemilihan baju, alat bermain maupun teman bermain,

Memang tidak semua anak tidak memahami identitas dirinya, paling tidak identitas jenis kelaminnya, saat memasuki dunia sosial yang lebih luas. Saat anak memasuki masa PAUD, anak belajar mengembangkan ketertarikannya dan mengekplorasi berbagai kemungkinan termasuk juga identitas diri dalam konsep yang lebih luas. Anak tidak sekedar belajar tentang konsep jenis kelamin yang dia miliki namun dia mengidentifikasi jenis kelamin anggota keluarganya, teman-temannya bahkan orang di luar lingkungan keluarga atau sekolah. Anak juga belajar konsekuensi yang dihubungkan dengan keberadaan jenis kelamin seperti ragam nama, sebutan pengganti nama, karaktersitik fisik maupun penampilan. Beberapa kajian pada anak usia dini menguatkan pemikiran pentingnya pendidikan gender, sebagaimana yang dikaji Hardianti (2017), Tandayu dan Masiuvah (2017), Jatmikowati dkk (2015), Shobahiya (2012).

Mata kuliah Wawasan Gender merupakan salah satu mata kuliah yang ditempuh oleh mahasiswa Pendidikan Guru PAUD, yang memberikan wawasan pada para calon guru tentang pentingnya mengenalkan anak identitas gender dengan tidak sekedar mengenal jenis kelamin belaka. Wawasan gender juga mengenalkan anak pada konsekuensi yang menyertai jenis kelamin yang dimilikinya untuk mengkonstrak pentingnya anak melindungi bagianbagian sensitif yang memungkinkan untuk perbuatan yang tidak bertanggung jawab dari orang dewasa di sekitar anak. Fakih $(2013 ; 8)$ menyatakan bahwa jenis kelamin merupakan sifat yang kodrati sedangkan gender merupakan sifat hasil konstrak sosial. Mata kuliah Wawasan Gender membantu mahasiswa memahami fungsi gender dan dialektika yang muncul 
sebagai wujud konstruksi sosial yang melekat pada jenis kelamin seseorang sehingga tidak membentuk stereotip yang keliru. Misalnya menekan kebiasaan untuk menyatakan, anak laki-laki harus kuat, anak laki-laki tidak boleh cengeng, bantu teman perempuannya, kan mereka lebih lemah dan sebagainya.

Pada semester ganjil 2018-2019, sebagian besar mahasiswa PGPAUD yang menempuh mata kuliah wawasan gender adalah guru aktif yang mengajar di kelompok bermain atau pun taman kanak-kanak. Meski demikian pemahaman yang diketahui mereka tentang gender dihubungkan secara terbatas dengan perbedaan jenis kelamin sebagaimana yang selama ini mereka ajarkan pada peserta didik sebagai bagian pengenalan identitias diri. Sedikit lebih jauh, para guru itu mengajarkan pengenalan gender melalui panggilan seperti laki-laki dewasa dipanggil dengan sebutan Bapak, Om, Mas, Abang dan panggilan yang bersifat kultural dalam bahasa daearah. Demikian juga dengan perempuan yang lebih dewasa dipanggil dengan sebutan Ibu, Tante, Mbak dan panggilan sesuai budaya setempat.. Para mahasiswa yang juga guru menyatakan pengenalan jenis kelamin merupakan suatu materi pembelajaran di tema awal yang berhubungan dengan identitas diri anak,

Selain itu idnetitas gender yang dikenalkan pada anak usia dini adalah dengan mengenali tampilan fisik untuk membedakan jenis kelamin seseorang, sehingga tak jarang justru membentuk stereotip-stereotip seperti perempuan berambut panjang, laki-laki berambut pendek, perempuan pakai perhiasan, lakilaki tidak pakai perhiasan, perempuan memakai rok sedangkan laki-laki memakai celana.. Konsep gender yang dihubungkan dengan penampilan fisik juga dihubngkan dengan bentuk peran sosial. Perempuan selalu digambarkan sebagai makhluk yang lemah, tidak memiliki kekuatan secara fisik sehingga cenderung melakukan peran atau pekerjaan yang tidak memerlukan kekuatan fisik, pekerjaan bersifat domestik,atau pekerjaan yang tidak memerlukan keterampilan berpikir kritis. Ada sebagian konteks perempuan melakukan pekerjaan yang menggunakan kemampuan berpikir namun diimbangi dengan kelembutan atau sikap sabar, seperti menjadi guru, perawat, sekretaris. Sebaliknya sosok laki-laki selalu digambarkan sebagai seseorang yang memiliki kelebihan kekuatan fisik dan kemampuan berpikir yang lebih kritis sehingga mampu melakukan peran dan pekerjaan yang membutuhkan kekuatan fisik atau pekerjaan yang menuntut kemampuan berpikir kritis. Dikhotomi peran yang tergambar dalam bentuk pekerjaan meskipun sebagian besar sudah dipahami oleh mahasiswa bahwa kurang tepat memberi pengetahuan yang demikian pada anak, tetap sulit mereka 
hindari karena keterbatasan konsep tentang gender.

Ada tiga kompetensi yang direncanakan yang ingin dikembanglatihkan dalam mata kuliah Wawasan Gender. Pertama, mahasiswa dapat menganalisis konsep identitas gender yang akan dikonstrakan pada anak. Kedua, mahasiswa memiliki pengetahuan teori gender untuk anak usia dini, dan mampu mensintesa guna mengembangkan kegaitan belajar di PAUD. Ketiga, mahasiswa mampu merancang dan mengimplementasikan rencana pengembangan pembelajaran bermuatan wawasan gender untuk PAUD. $\mathrm{Ke}$ tiga kompetensi merupakan bekal calon guru/guru untuk mentranformasi pembelajaran berbasis gender untuk anak usia dini.

Tujuan dari penelitian ini untuk mendeskripsikankan perkembangan pemahaman dan kemampuan calon guru Pendidikan Anak Usia Dini (PAUD) dalam merancang dan melaksanakan pembelajaran berwawasan gender pada anak usia dini.dalam mata kuliah Wawasan Gender di prodi PG PAUD UM Jember. Analisis kebutuhan perbaikan pemahaman konsep Wawasan Gender pada calon guru/guru PAUD didasari dari kajian pada minggu-minggu awal perkuliahan terkait dengan keterbatasan pengetahuan tentang konsep dan pengembangan kegiatan belajar yang bermuatan gender di PAUD, serta kajian pustaka tentang keterbatasan pendidikan gender yang dilakukan oleh orang tua. Magnuson et al (2015) mengkaji secara meta-analisis apakah terdapat dampak efektivitas atas pendidikan gender di PAUD yang merupakan kebijakan pendidikan di AS terhadap luaran pengetahuan, kemampuan akademis, perilaku maupun pengaruh orang dewasa. Temuaan yang signifikan terdapat pada luaran pengetahuan dan prestasi pemahaman konsep gender yang bagus pada anak laki-laki dan perempuan, Sedangkan Garcia, Heckman dan Ziff membuktikan bahwa pengaruh pendidikan gender dari orang tua memberi keuntungan pelaksanaan gender di PAUD sehingga dapat mengurangi kesenjangan perilaku anak laki-laki dan anak perempuan saat di sekolah. Kecenderungan yang terjadi hasil pendidikan gender oleh orang tua khususnya ayah lebih memperhatikan anak-laki-laki dibandingkan anak perempuan. Pendidikan gender di PAUD mengurangi gap superioritas anak lakilaki terhadap anak perempuan. Kajian yang dilakukan oleh Warin dan Adriany (2015) menjelaskan peran PAUD dalam konstruksi konsep "paedagogik fleksibel gender" berkaitan dengan bentuk alternative permodelan maskulinitas maupun feminitas.

Penerapan metode proyek bagi mahasiswa terbukti efektif untuk meningkatkan pengetahuan dan pemahaman mahasiswa terhadap kajian teoretik dan keterampilan mengajar calon 
guru PAUD. Metode proyek merupakan bagian dari strategi pembelajaran kooperatif (Slavin, 1997; 289), yaitu suatu metode pembelajaran yang berbasis pada kegiatan belajar yang dilakukan dalam kelompok untuk menghasilkan suatu produk. Sedangkan Jackman (2012; 26) mengartikan metode proyek sebagai proyek ada kegiatan investigasi yang mendalam terhadap topik yang sedang dibahas. Kajian Cohrssen dan Tayler (2015) menunjukkan penguatan rekonstualisasi untuk meningkatkan efektivitas mengajaran pada pembelajaran matematika awal melalui pengembangan rencana pembelajaran berbasis bermain pada mahasiswa PGPAUD. Park, GuangLee dan Hoot (2019), Briody (2005) melatih calon guru mengembangkan sensitivitas akan anak usia dini melalui melalui kegiatan sebagai relawan di shelter anak-anak tuna wisma. Dever (20016) menrapkan metode proyek untuk mengembangkan keterampilan sosial calon guru dalam memberikan advokasi pada anak-anak bermasalah. Adapun kajian tentaang pentingnya mengonstrak pengetahuan calon guru tentang Wawasan gender dikaji oleh Blanchard et al (2017), Nell (2007) Sugawara, Burt dan Ruder (2006), Pettit dan Sugawara (2002). Dalam kajian tentang gender di PAUD ketiga penelti ini memangang gender sebagai bagian dari identifikasi perbedaan dari baragam sudut pandang anak usia dini. Penguatan mahasiswa lebih menekankan pada pengembangan sensitivitas anak untuk memahami keberagaman di sekar anak. Kajian-kajian itu tidak membahas lebih dalam tentang pengembangan konsep gender bagi calon guru.

\section{METODOLOGI}

Penelitian ini merupakan penelitian kualitatif dengan strategi studi Kasus. Creswell (2015) menjelaskan studi kasus sebagai strategi penelitian secara cermat aktitivitas, periatiwa, proses atau sekelompok individu yang dibatasi oleh waktu dan aktivitas. Dalam kajian ini, ada dua masalah yang akan diteliti, pertama, bagaimana mahasiswa menerapkan boneka gender sebagai media pembelajaran untuk mengenalkan anak pada identitas dan peran gender sesuai tahap perkembangan anak.. Kedua, bagaimana proses pengembangan keterampilan mahasiswa merancang skenario pembelajaran pendidikan gender untuk anak usia dini melalui metode proyek.

Subyek dalam penelitian ini adalah 5 kelompok mahasiswa PG PAUD Universitas Muhammadiyah Jember yang menjadi peserta mata kuliah Wawasan Gender berjumlah keseluruhan 17 orang. Dikarenakan kegiatan penugasan dengan metode proyek yang dilakukan dengan bentuk kelompok maka informan kunci dipilih dari anggota kelompok yang memiliki performa akti dan cenderung menjadi pengarah dalam diskusi. Terdapat 5 orang informan kunci yang mewakili masing-masing kelompok. 
Penelitian dilaksanakan pada paruh kedua semester ganjil tahun 20182019, yaitu sesudah dilaksanakan evaluasi hasil ujian tengah semester hingga masa evaluasi pembelajaran sebelum ujian Akhir Semester. Tempat penelitian di Fakultas Keguruan dan Ilmu Pendidikan Universitas Muhammadiyah Jember, Jawa Timur.

Teknik pengumpulan data dengan menggunakan portofolio tugas, wawancara dan observasi. Portofolio tugas dikoleksi dari hasil ujian tengah semester dan tugas mingguan terstruktur dan tugas mandiri berupa perangkat pembelajaran dan dokumentasi hasil praktek mengajar di lapangan. Portofolio tugas juga diperoleh dari tahapan menyelesaikan tugas terstruktur berupa proyek boneka gender. Wawancara dilakukan dengan informan kunci secara mendalam untuk mengetahui kelemahankelemahan dalam pemahaman pengetahuan maupun pengembangan skenario serta untuk mendapatkan informasi reaksi anak saat belajar tentang gender. Sedangkan untuk kegiatan observasi dilaksanakan saat mahasiswa menyusun tugas terstruktur di kelas, yaitu saat menyusun skenarion pembelajaran.

Teknik analisis data dalam bentuk analisis kritis - naratif, yaitu bentuk analisis data yang didasarkan pada display data hasil temuan dan kategorisasi yang kemudian dianalisis secara naratif dan didiskursuskan dengan kajian teoretik. Jadi tidak dilaksanakan paparan data yang diperoleh secara keseluruhan sesudahnya baru dianalisis. Dengan demikian akan diperoleh suatu gambaran yang lebih terpadu atas suatu peristiwa atau proses yang telah dilakukan. Hal ini juga sebgai upaya uji reliabilitas atas kekonsistenan peneliti dalam mendokumentasikan langkah-langkah dan prosedur yang telah dilakukan dalam penelitian.

Teknik validasi data dilakukan dengan triangulasi sumber-sumber data yang berbeda, dalam hal ini dengan mencek hasil tugas mahasiswa yang bukan subyek penelitian serta studi pustaka terhadap penelitian sejenis. Validitas kedua juga dilakukan dengan menyajikan informasi :yang berbeda" atau "negative" yang dapat meberi perlawanan pada hasil temuan atau dokumentasi yang diperoleh. Teknik validasi ketiga yang diterapkan adalah external auditor yang lebih pakar dalam penelitain kualitatif dan penelitian pendidikan.

\section{HASIL DAN PEMBAHASAN}

Di awal perkuliahan, pengetahuan mahasiswa tentang gender selalu dihubungkan dengan pendidikan tentang jenis kelamin serta tindakan yang dilekatkan pada jenis kelamin tersebut. Sebagian besar mahasiswa adalah guru yang sudah mengajar di PAUD, baik taman kanak-kanak maupun kelompok bermain. Ketika ditanyakan pengalaman 
mereka mengajar tentang konsep gender yang dikenalkan ke anak usia dini, ratarata mahasiswa menjawab mereka mengenalkan jenis kelamin, perbedaan fisik berdasararkan jenis kelamin dan konsekuensi sosio kultural dari perbedaan jenis kelamin itu. Mahasiswa mengakui bahwa pengetahuan mereka tentang gender sangat terbatas. Pengetahuan tentang gender diketahui dari hasil sosialisasi saat kegiatan gugus atau berasal dari teman yang meungkin mengikuti seminar dengan tema gender.

Dari hasil curah pendapat di minggu awal, diperoleh informasi bahwa pengenalan tentang identitas gender di PAUD biasanya dikenalkan melalui tema Identitas Diri, Keluargaku, dan Pekerjaan. Yang dilakukan dalam mengenalkan gender pada anak adalah dengan mengenalkan jenis kelamin anak kemudian mengenali ciri-ciri yang membedakan antara jenis kelamin itu. Sebagian besar mahasiswa merupakan guru yang mengajar di layanan PAUD yang berbasis agama (keseluruhan Islam) dan berada di wilayah pinggiran atau perdesaan. Tidak jarang anak tidak mengetahui istilah untuk jenis kelaminnya atau pun bila mengenali anak mengetahui dengan istilah bahasa daerah setempat. Karenanya mengenalkan identitas diri anak khususnya perbedaan jenis kelamin dalam bahasa nasional dianggap penting.

Dengan latar belakang anak yang demikian saat masuk PAUD, maka guru beranggapan perlu pula mengenalkan konsekuensi logis dari jenis kelamin yang mereka miliki. Mengenalkan ciri-ciri fisik yang melekat pada anak didasarkan dari jenis kelamin tersebut, konsekuensi tindak kultural yang harus dilakukan merupakan pengembangan berikutnya setelah anak mengenal jenis kelaminnya. Mengenalkan perbedaan jenis kelamin dengan mendasarkan pada ciri fisik yang nampak seringkali memunculkan stereotip yang kemudian melekat pada keberadaan identitas seseorang. Pada guru yang mengajar di sekolah yang berbasis agama mereka menunjukkan perbedaan jenis kelamin dari pakaian yang dikenakan anak dalam keseharian di sekolah. Anak perempuan memakai jilbab sedangkan anak laki-laki memakai kopiah. Anak perempuan memakai rok/gamis sedangkan anak laki-laki bercelana.Atau guru juga mengambil sosok dewasa sebagai contoh seperti Ayah tidak memakai lipstick, ibu memakai lipstick.

Pernyataan ini seringkali memunculkan bahasan kritis ketika anak memasuki jenjang kelas yang lebih tinggi. Ketika membahas sub tema yang sama di jenjang yang lebih tinggi, tak jarang guru mendapat pertanyaan/pernyataan, kalau di rumah aku juga pakai celana, ibuku juga pakai celana kayak ayah, di rumah aku tidak pakai jilbab merupakan sebagian pernyataan yang disaampaikan oleh anak perempuan. Pernyataan/pertanyaan dari siswa laki-laki juga merupakan antitesa 
dari informasi yang diperoleh anak dari guru, seperti kalau sholat aku sama ayah pakai sarung, mengapa aku tidak boleh pakai jilbab, mengapa aku tidak boleh lipenan (memulas bibir dengan lipstick).

Tak jarang dalam pengembangan pembahasan tentang gender guru terjebak pada konsekuensi yang sosio kultural yang sering nampak di llingkungan sekitar. Misalnya mengaitkan peran gender seseorang dengan penampilan fisik, pekerjaan yang dilakukan, atau tata karma yang mengikat seseorang. Ratarata mahasiswa menyatakan ketika berbicara tema pekerjaan, mereka cenderung mengenalkan pada anak-anak pekerjaan untuk laki-laki dan pekerjaan untuk perempuan. Sebagian kecil mahasiswa menyatakan mereka sudah mengurangi bias pernyataan yang demikian namun kadang kala masih terjebak dengan sebutan tertentu terkait dengan pekerjaan, seperti Pak polisi, Pak dokter, bu guru dan lainnya.

Kondisi yang demikian nampak ketika mahasiswa diminta untuk menyusun skenario pembelajaran sebagai bentuk tugas terstruktur. Kegiatan ini dilaksanakan dalam bentuk kelompok, dengan menggunakan tema Pekerjaan. Meskipun pada saat brainstorming mahasiswa telah mendapatkan materi untuk menghindari stereotip yang mungkin terjadi pada tema ini, masih terdapat kelompok yang dalam uraiannya menyebutkan tentang pekerjaan perempuan sebagai Ibu Rumah Tangga dengan tugas memasak, membersihkan rumah dan mendidik anak. Pada kelompok lain nampak mengalami kesulitan mengembangkan skenario belajarnya. Ketika ditanyakan tentang kesulitan mengembangkan skenario, anggota kelompok menjawab mereka kesulitan dalam mengembangkan kalimat-kalimat untuk mengenalkan pokok bahasan pada anak.

Berdasarkan dari kondisi ini, mahasiswa diarahkan untuk membuat media yang dapat menjadi jembatan menyampaikan konsep gender pada anak usia dini. Boneka gender menjadi proyek bersama yang dalam konsep dan pengembangan pembuatannya dirancang bersama. Disebut boneka gender karena boneka ini dirancang untuk membantu anak memahami konsep identitas diri dan peran gender yang dikonstruksikan. Boneka gender terdiri dari 2 pasang boneka, yaitu sepasang boneka yang menampilkan sosok laki-laki dan perempuan dewasa, dan sepasang boneka menampilkan sosok anak-anak laki-laki dan perempuan. Boneka gender ini dilengkapi dengan alat kelamin sesuai jenisnya, tampilan fisik dan baju sesuai sosoknya. Produksi Boneka gender diselesaikan dalam 2 minggu. 


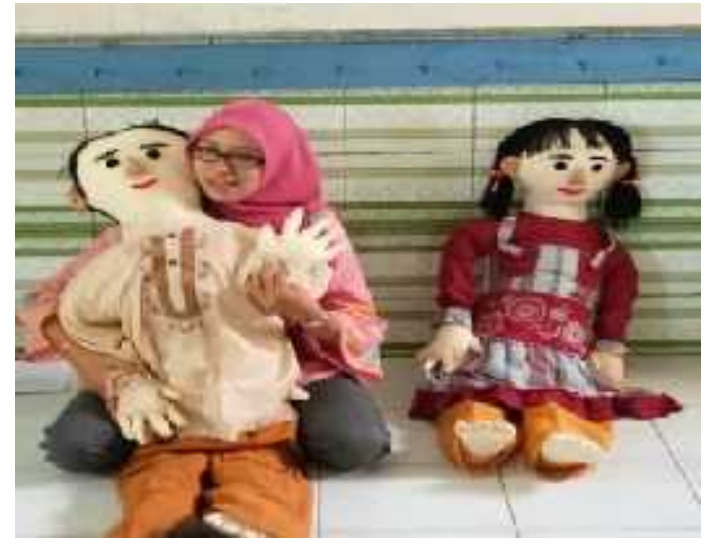

Gambar 1. Boneka gender dewasa

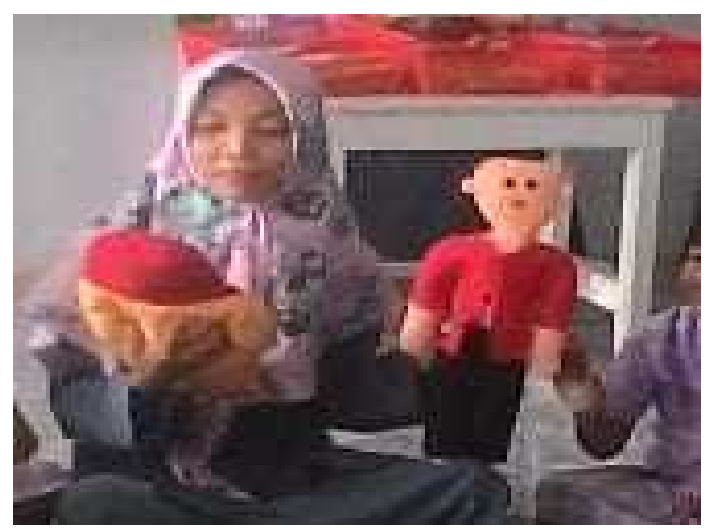

Gambar 2. Boneka Gender anak-anak

Sesudah Ujian Tengah Semester, mahasiswa diminta untuk memperbaiki skenario terakhir yang dibuat dengan memasukkan boneka gender sebagai media. Terdapat 5 mahasiswa dari masing-masing kelompok sudah menunjukkan perbaikan dalam skenarionya. Terutama dalam pengembangan kegiatan pembelajarannya. Detail pembahasan dari tema yang diangkat nampak lebih runtut dibandingkan sebelum menggunakan media boneka.
Nampaknya boneka gender sebagai media memberikan kemudahan bagi mahasiswa mengembangkan kelas imanjinatif yang memudahkan mereka mengembangkan skenario pembelajaran. Lemish (2015;39) menyatakan media yang dihubungkan dengan kegiatan yang dilakukan nampak lebih berpengaruh karena 5 kriteria seseorang mampu berimanjinasi. Pertama, terkonstruksi, bahwa tingkat pemahaman seseorang dapat dibantu dengan kehadiran media yang dapat disetarakan dengan realitas yang akan ddihadapi. Kedua, aktualitas fisik, yaitu kemampuan seseorang mengevaluasi kenyataan berdasarkan persepsi terhadap kemungkinan realitas yang akan dihadapi. Ketiga, kemungkinan yang terjadi, kemampuan seseorang mempertimbangkan kemungkinan kendala dan keberhasilan yang akan dihadapi. Ke empat, probabilitas, yaitu persepsi seseorang mengevaluasi realitas yang mewakili kondisi nyata yang akan dihadapi. Ke lima, bagaimana seseorang memahami ungkapan atau istilah formal sebagai hal yang dapat digunakan atau tidak di kondisi nyata.

Kriteria yang disampaikan Lemis tersebut menggambarkan bagaimana media boneka gender memudahkan mahasiswa mengkonstruksi kelas, siswa dan situasi yang akan dihadapi sehingga mahasiswa dapat meminimalisir kendala secara fisik maupun psikologis yang dapat terjadi. Mahasiswa juga terbantu untuk menganalisis kebutuhan anak yang 
dapat dengan mudah konsepnya dipahami dan digunakan. Misal bentuk alat kelamin pada boneka dapat membantu anak memahami perbedaan fisik yang tidak tampak dalam keseharian mereka. Guru juga lebih mudah menyampaikan tidak dalam bahasa verbal namun cukup dengan menunjukkan bagian genital boneka. Wortham (1998; 185) menyatakan salah satu peran seorang guru PAUD adalah menggunakan lingkungan dan kegiatan pembelajaran untuk menfasilitasi proses pembelajaran. Media merupakan "jembatan" bagaimana guru PAUD menyusun skenario pembelajaran. Media memberikan kemungkinan guru mempertimbangkan solusi atas kendala yang dihadapi ketika proses pembelajaran.

Keterampilan menyusun skenario pembelajaran juga menampakkan kemajuan. Tidak semua kelompok menggunakan boneka gender secara lengkap. Ada kelompok yang menggunakan boneka gender dewasa, ada juga kelompok yang menggunakan boneka gender anak-anak. Hal ini mempengaruhi mahasiswa dalam menyusun pengembangan scenario pembelajaran, sebagaimana dapat dilihat dalam tabel berikut:

\section{Tabel 1. Perbandingan Skenario Sebelum dan Sesudah Menggunakan Metode Proyek}

\begin{tabular}{|c|c|}
\hline Skenario Awal & $\begin{array}{c}\text { Skenario Revisi } \\
\text { Akhir }\end{array}$ \\
\hline Kelompok Usia : B & Kelompok/ \\
\hline Kegiatan & : TK A (4-5 \\
\hline Bercakap-cakap & Tahun) \\
\hline Tema/Sub tema: & Kegiatan \\
\hline Kebersamaan & . \\
\hline dalam & berperan \\
\hline $\begin{array}{l}\text { Keluarga/mengenal } \\
\text { anggota keluarga }\end{array}$ & $\begin{array}{lr}\text { sebagai } & \text { polisi dan } \\
\text { polwan } & \text { yang }\end{array}$ \\
\hline Tujuan: & sedang mengatur \\
\hline $\begin{array}{l}\text { - Anak mampu } \\
\text { menyebutkan }\end{array}$ & $\begin{array}{l}\text { lalu lintas. } \\
\text { Tema/Sub }\end{array}$ \\
\hline jumlah anggota & : \\
\hline kelaurga kecilnya & Profesi/Polisi \\
\hline dan & Metode \\
\hline panggilan & : Bermain \\
\hline anggota keluarga & Peran \\
\hline Strategi & Tujuan \\
\hline Pembelajaran: & . \\
\hline bercerita & mampu \\
\hline Langkah & mengetahui bahwa \\
\hline Pembelajaran: & Polisi wanita dan \\
\hline $\begin{array}{l}\text { 1.Anak membentuk } \\
\text { lingkaran seblum }\end{array}$ & $\begin{array}{l}\text { laki-laki adalah } \\
\text { ciptaan Tuhan (1.1) }\end{array}$ \\
\hline kegiatan & mampu \\
\hline $\begin{array}{l}\text { 2. Guru memberi } \\
\text { salam }\end{array}$ & $\begin{array}{l}\text { menunggu giliran } \\
\text { ketika bermain }\end{array}$ \\
\hline 3. Guru & memerankan \\
\hline menjelaskan & menjadi \\
\hline tema hari ini & wanita dan laki- \\
\hline 4. Guru & laki (2.7) \\
\hline menunjukkan & mampu \\
\hline
\end{tabular}




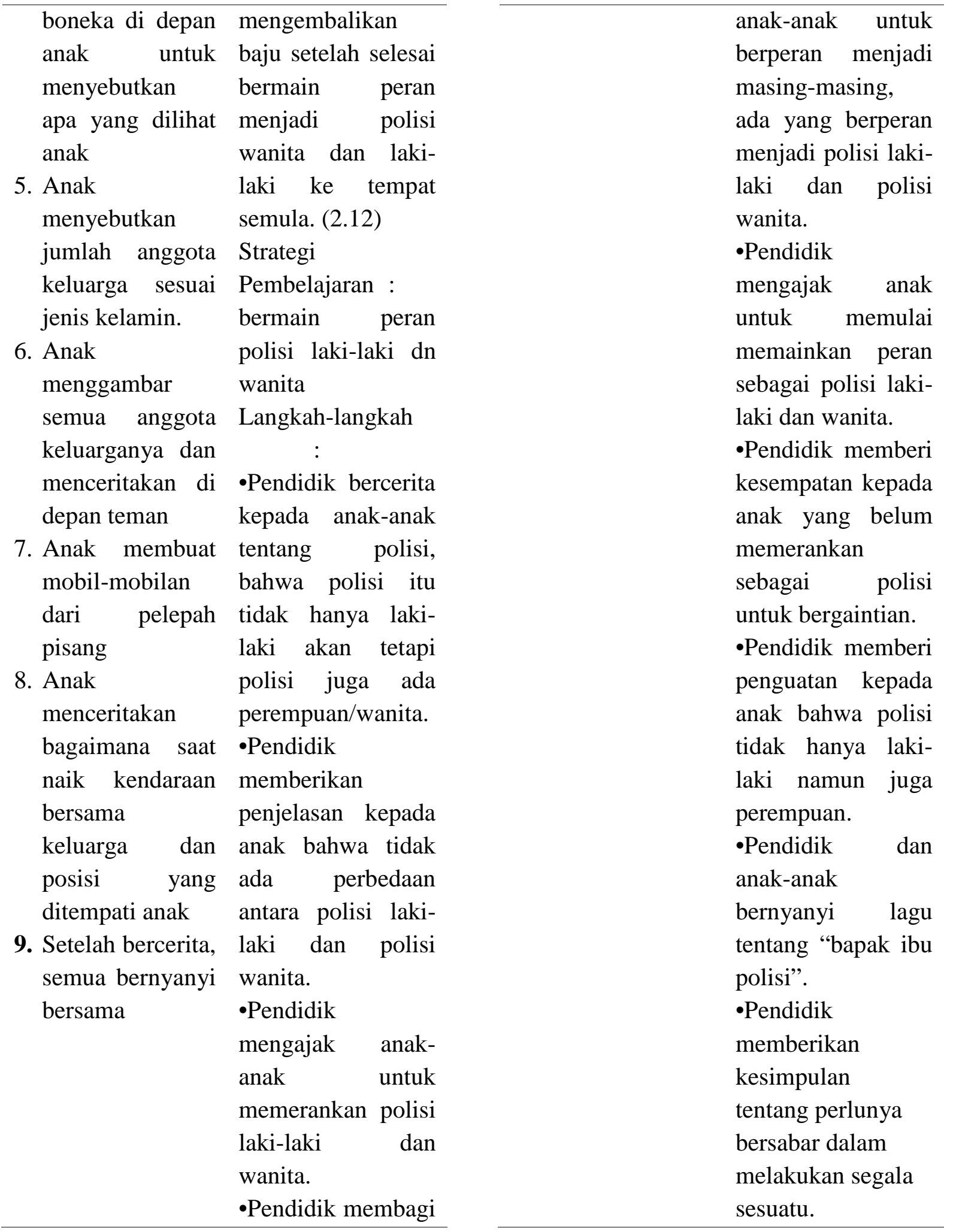


Dari tabel 1 dapat diketahui kesulitan mahasiswa mengembangkan topik bahasan yang berkaitan dengan gender. Mahasiswa nampak tidak mampu mengembangkan lebih jauh materi dikaitkan dengan topik gender, sehingga pembahasan berhenti pada kegiatan menghitung jumlah anggota keluarga sesuai jenis kelamin. Berbeda dengan setelah mahasiswa terlibat dalam proyek boneka gender (skenario revisi akhir). Mahasiswa mampu mengembangkan kegiatan pembelajaran secara runtut tanpa diselingi kegiatan lain.

Skenario sebagaimana kolom pertama tidak hanya dialami oleh satu kelompok sebelum terlibat dalam proyek boneka gender. Pada kelompok lain, mengusung kegiatan bermain peran dengan tujuan mengenalkan anak pada perbedaan toilet laki-laki dan perempuan yang ditandai oleh gambar laki-laki dan perempuan. Kelompok lain membahas video tentang keluarga dan dilanjutkan dengan kegiatan membahas figure ayah dan ibu. Kegiatan diikuti dengan mewarnai gambar ayah dan ibu. Dari ke tiga kelompok tersebut nampak bahwa mahasiswa tidak tahu bagaimana mengembangkan pembahasan yang lebih fokus pada gender.

Selama pengembangan boneka gender, mahasiswa juga terus memperbaiki skenario pembelajarannya. Pada saat yang sama mahasiswa lebih fokus memahami kendala pengetahuan wawasan gender yang masih berputar hanya pada perbedaan jenis kelamin tanpa menyertakan fungsi gender seperti peran yang dilekatkan pada seseorang. Melalui media boneka, mahasiswa mengembangkan sintesa pengetahuan teoretis gender yang dipelajari dengan perencanaan topik yang bisa disampaikan dengan menggunakan boneka tersebut sebagai media. Hal ini yang mampu membantu mahasiswa secara konstruktif mengembangkan rancangan yang runtut tanpa menyelingi dengan kegiatan lain.

Pelibatan boneka gender memang tidak terus menerus dalam suatu rancangan yang dikembangkan sebagaimana dapat dibaca dalam skenario revisi terakhir. Pengetahuan yang lebih luas dan komprehensif dari materi kuliah juga memungkinkan mahasiswa mengembangkan rancangan yang konstruktif berbasis gender. Konstruksi peran gender merupakan sautu konstruksi sosial yang melekat pada jenis kelamin seseorang dengan menekankan pada pengurangan bias gender yang juga disebabkan oleh dikotomi jenis kelamin. Pemahaman ini yang diperoleh mahasiswa sehingga mahasiswa juga mampu mereduksi atau setidaknya meminimalisir hal-hal yang bersifat bias gender, seperti bahwa peran seseorang ditentukan oleh jenis kelaminnya, atau dalam pemahaman konkrit anak pekerjaan seseorang tidak selalu dihubungkan dengan jenis kelamin. Setiap orang memiliki kesempatan yang sama untuk bekerja pada suatu bidang. 
Pada salah satu rancangan skenario, mahasiswa menjelaskan tentang profesi sebagai petinju. Fakih $(2013 ; 21)$ menyebut hal tersebut sebagai bias gender yang berhubungan dengan beban kerja. Skenario pembelajaran yang telah direvisi ini kemudian menjadi dasar mahasiswa melaksanakan praktek lapangan sebagai bentuk Ujian Akhir Semester. Beberapa mahasiswa bahkan menyiapkan lebih dari satu skenario pembelajaran. Alasan mereka membuat lebih dari satu skenario karena sekarang merasa ada banyak hal yang bisa disampaikan tidak hanya terkait dengan jenis kelamin saja atau tentang sebutan yang sesuai jenis kelamin seseorang. Kegiatan pembelajaran di lapangan memperoleh antusiasme anak karena media boneka gender yang dibawa oleh mahasiswa lebih dapat dimanipulasi oleh anak.

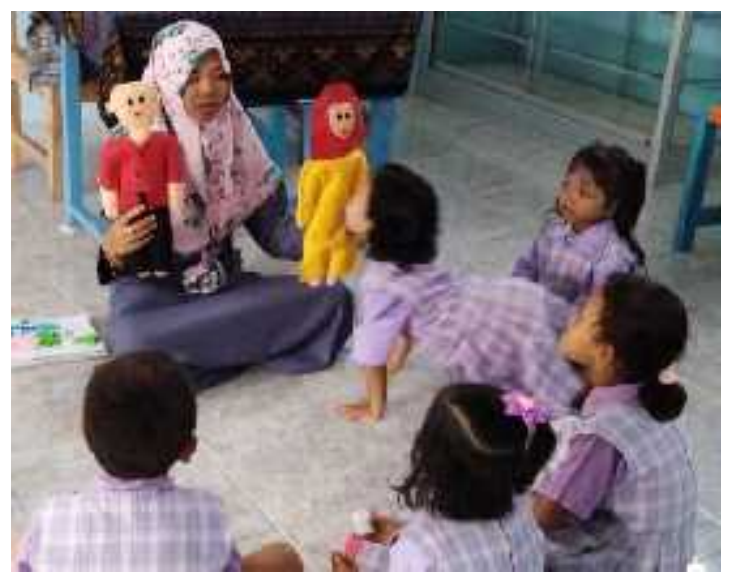

Gambar 3. Praktek lapangan

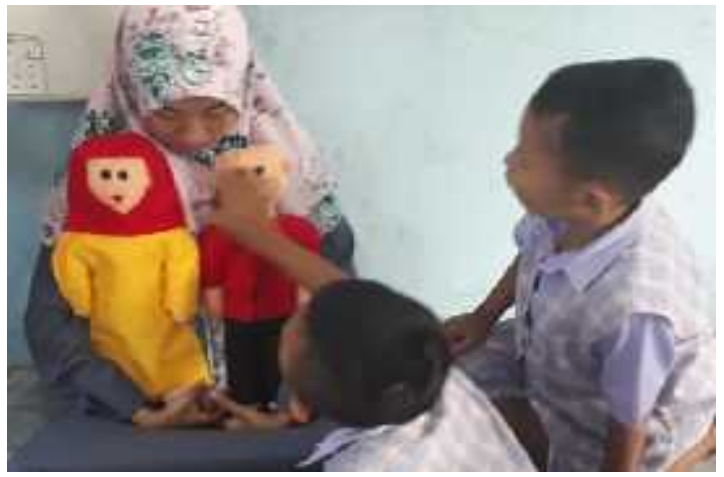

Gambar 4 Praktek Lapangan

\section{KESIMPULAN}

Salah satu kelemahan mahasiswa peserta mata kuliah Wawasan Gender adalah mengembangkan skenario pembelajaran berwawasan gender yang dapat mengkonstruksi anak memahami konsep-konsep yang tidak sekedar terjebak pada perbedaan jenis kelamin. Proyek boneka gender yang dikembangkan mahasiswa sebagai media pembelajaran untuk mengenalkan anak pada identitas dan peran gender memudahkan mahasiswa mengonstruksi sintesa pengetahuan wawasan gender untuk diterapkan dalam rancangan kegiatan pembelajaran sesuai tahap usia anak.

Kondisi di kelas, mahasiswa tidak segera melakukan harmonisasi antara pengetahuan yang memungkinkan mereka mengembangkan pembelajaran yang efektif nantinya. Harmonisasi pengetahuan calon guru diperlukan agar kelak saat menjadi guru mampu mentransformasikan pengajaran yang efektif. Oleh karenanya upaya yang 
berkelanjutan untuk menyeimbangkan pemahaman mahasiswa terhadap konten, kurikulum, tujuan pembelajaran dan asesmen harus tetap dilaksanakan.

\section{DAFTAR PUSTAKA}

[1] Blanchard, S. B, et.al. 2018. Diversity, inclusion, equity, and social justice: How antibias content and self-reflection support early childhood preservice teacher consciousness. Journal of Early Childhood Teacher Education. Volume 39, 2018 - Issue 4. https://doi.org/10.1080/10901027.2 $\underline{017.1408722}$

[2] Cohrssen, C dan Tayler, C. 2016. Early childhood mathematics: A pilot study inpreservice teacher education. Journal of Early Childhood Teacher Education. Volume 37, 2016 - Issue 1. https://doi.org/10.1080/10901027.2 $\underline{015.1131208}$

[3] Dever, M.T. 2007. Advocating for Young Children: A PreserviceTeacher Education Project. Journal of Early Childhood Teacher Education. Volume 27, 2006 - Issue 4. https://doi.org/10.1080/1090102060 0996299

[4] Garcia, L.G, Heckman, J.J, Ziff, A.L. 2018. Gender Differencesin the Benefits of an Influential Early Childhood Program. Europen Economic Review. 10.1016/j.euroecorev.2018.06.009

(10 Maret 2019)

[5] Hardianti. A.N. 2017. Pendidikan Gender Untuk Anak Usia Dini. http://journal.ummgl.ac.id/index.ph p/edukasi/article/download/599/390 /. (11 Maret 2019)

[6] Henniger, M.L. 2013. Teaching Young Children: An Introduction. NJ: Pearson

[7] Jackman, H.L., Early Education Curriculum: A Child's Connection to the World. USA:Wadsworth, 2012.

[8] Jatmikowati dkk. 2015 Model Dan Materi Pendidikan Seks Anak Usia Dini Perspektif Gender Untuk Menghindarkan Sexual Abuse. https://scholar.google.co.id/citations ?user=xzMLabwAAAAJ\&hl=en\&o i=sra.(11 Maret 2019)

[9] Lemish, D. 2015. Children and Media: A Global perspective.. Willey Blackwell. UK

[10] Magnuson, K.A et al. 2016. Do The Effect of Early Childhoodeducation program differ by gender? A Metaanalysis.Early Childhood Research Quarterly http://dx.doi.org/10.1016/j.ecresq.20 15.12.021

[11] Slavin, R. E., Educational Psychology: Theory and Practice. 5th edition, Massachussest: Allyn and Bacon, 1997.

[12] Gender, Age, Ses, And Activity Type As Factors Contributing To 
Early Childhood Preservice

Teachers' Interactions With

International And U.S. Preschool

Children. Journal of Early

Childhood Teacher Education.

Volume 21, 2000 - Issue 1.

https://doi.org/10.1080/0163638000

210112

[13] Tandayu, D. Syukri, M, Masiuyah. Pengenalan Peran Gender pada Anak Usia 5-6 tahun di TK. http://jurnal.untan.ac.id/index.php/j pdpb/article/download/10203/9898

(11 Maret 2019)

[14] Wardhani. W.D.L. 2016. Kontruksi Identitas dan Peran Gender pada Anak Usia Dini. http://jurnal.unmuhjember.ac.id/ind ex.php/pslcf/article/download/912/ 726. (11 Maret 2019)

[15] Warin. J dan Adriany, V. 2015. Gender Flexible pedagogy in early childhood education.

Journal of Gender Studies. Vol. 26. $2017 . \quad$ Issue 4. https://doi.org/10.1080/09589236. 2015.1105738

[16] Park, S.R, Lee, G dan Hoot, J.L.2018. Developing preservice teachers' sensitivity and confidence: a service-learning experience at a homeless shelter. Journal of Early Childhood Teacher Education. Volume 40, 2019 - $\quad$ Issue 1. https://doi.org/10.1080/10901027. $\underline{2019.1573206}$ 